\title{
PENGARUH PENERAPAN ERP TERHADAP WAKTU TEMPUH FEEDER DAN WAKTU TEMPUH PERJALANAN RUAS JALAN GATOT SUBROTO
}

\author{
Sherly Octaviani ${ }^{1}$ dan Najid $^{2}$ \\ ${ }^{1}$ Program Studi Sarjana Teknik Sipil, Universitas Tarumanagara, Jl. Letjen S. Parman No.1 Jakarta \\ sherly.325150191@stu.untar.ac.id \\ ${ }^{2}$ Program Studi Sarjana Teknik Sipil, Universitas Tarumanagara, Jl. Letjen S. Parman No.1 Jakarta \\ Najid2009@yahoo.com
}

Masuk: 05-07-2020, revisi: 04-09-2020, diterima untuk diterbitkan: 22-10-2020

\begin{abstract}
Electronic Road Pricing is a paid road used to reduce the volume of traffic by pairing On Board Unit for payment. The high volume of vehicles in Jakarta is the main reason Electronic Road Pricing is used in traffic. In this research, discussed about the traffic conditions of Gatot Subroto, this road section is main access to get to the office and travel. To analyze the volume of the vehicle, the direct observation method will be used to get the volume, speed and traffic density. Direct observation is done by paying attention to motorcycle, light vehicles, and heavy vehicles. With the observation data we will get a graph of the relationship between speed and speed that will be modified with questionnaire data. Questionnaire data is distributed to obtain percentages of volume reduction and price estimates. Electronic Road Pricing is used to reduce traffic volume. It is hoped that this research analysis can find out the most efficient cost of Electronic Road Pricing to reduce the volume of vehicles on the Gatot Subroto road.
\end{abstract}

Keywords: Electronic Road Pricing; Gatot Subroto; Transjakarta.

\begin{abstract}
ABSTRAK
Electronic Road Pricing adalah jalan berbayar yang digunakan untuk mengurangi volume lalu lintas dengan cara memasangkan alat On Board Unit sebagai alat pembayarannya. Tingginya volume kendaraan di Jakarta menjadi alasan utama Electronic Road Pricing digunakan pada lalu lintas. Pada penelitian ini, akan dibahas mengenai kondisi lalu lintas Gatot Subroto, ruas jalan ini merupakan akses pengguna untuk menuju perkantoran dan tepat wisata. Untuk menganalisa volume kendaraan akan digunakan metode observasi langsung untuk mendapatkan volume, kecepatan dan kepadatan lalu lintas. Observasi langsung dilakukan dengan memperhatikan kendaraan bermotor roda dua, kendaraan ringan, dan kendaraan berat. Dengan data observasi akan didapat grafik hubungan antara kecepatan dan kedapatan yang akan dimodifikasi dengan data kuesioner. Data kuesioner disebar untuk mendapatkan persentase penurunan volume dan perkiraan harga. Electronic Road Pricing untuk mengurangi volume lalu lintas. Diharapkan pada analisis penelitian ini dapat mengetahui biaya Electronic Road Pricing yang paling efisien untuk mengurangi volume kendaraan pada jalan Gatot Subroto.
\end{abstract}

Kata kunci: Electronic Road Pricing; Gatot Subroto; Transjakarta

\section{PENDAHULUAN}

Di kota besar seperti Jakarta, setiap harinya aktivitas lalu lintasnya sangat ramai dan padat. Hal ini terjadi karena tingginya angka penduduk yang berbanding lurus dengan mobilitas penduduknya, yang kemudian dapat menimbulkan permasalahan lalu lintas. Aktivitas lalu lintas yang sangat ramai dan padat inilah yang mengakibatkan sering terjadinya kemacetan di berbagai titik di Jakarta.

Pada dasarnya manusia butuh berpindah dari suatu tempat ke tempat yang lainnya. Perpindahan ini membutuhkan sarana transportasi yang dapat menunjang dari berbagai aspek yang dirasa dibutuhkan. Hingga saat ini, masyarakat jakarta dinilai masih lebih menggemari kendaraan pribadi dibandingkan dengan moda transportasi umum. Hal inilah yang dapat memicu kondisi kemacetan di Jakarta semakin parah.

Menurut Abubakar (2012), kapasitas jalan merupakan efisiensi ruas jalan yang sempurna dalam satuan waktu tertentu untuk menangkal arus atau volume lalu lintas, dalam satuan jam (kend/jam) yang dinyatakan dalam jumlah kendaraan yang melewati potongan jalan tertentu. Faktor utama yang menyebabkan terjadinya kemacetan di Jakarta adalah kapasitas jalan yang tidak memadai sedangkan pertumbuhan pembelian kendaraan bermotor baru semakin 
Subroto

meningkat. Bahkan masih ada faktor lain yang memperparah kemacetan di Jakarta, seperti; rekayasa lalu lintas yang diberlakukan, ruas jalan yang terpakai untuk proyek pengembangan kota,dan lain-lain.

Berbagai kebijakan peraturan telah diberlakukan oleh pemerintah dalam upaya mengurangi kemacetan di ibukota, seperti ganjil genap, fly over dan underpass. Salah satu metode yang akan diterapkan yaitu Electronic Road Pricing (ERP) yang sudah diidekan sejak tahun 2006 oleh Sutiyoso (Sorta Tobing. Kata data. Selasa, 19 November 2019).

Ada dua sistem ERP yang bisa diterapkan. Pertama, memakai teknologi tercanggih dengan satelit atau global positioning system (GPS). Kedua, dengan sistem berbasis frekuensi radio, seperti dedicated short range communication (DSRC), dengan memasang pintu gerbang (gantry). Cara ini sudah diterapkan oleh negara pertama yang menggunakan ERP, yaitu Singapura.

Sejak tahun 2004 pemerintah juga telah menghadirkan layanan sistem trasnportasi umum berupa BRT (bus rapid transit) atau yang dikenal dengan Transjakarta. Sesuai dengan visinya yaitu "menghubungkan kehidupan jakarta", transjakarta sampai saat ini telah memiliki jalur lintasan sepanjang $251,2 \mathrm{~km}$, serta memiliki 260 halte yang tersebar dalam 13 koridor. Tarif yang diberlakukan ialah Rp3.500,- sejak awal beroperasi hingga saat ini. Dalam upaya meningkatkan jumlah pengguna Transjakarta telah disediakan juga angkutan pengumpan (angkutan feeder). Angkutan pengumpan ini terintegrasi dengan halte Transjakarta lainnya. Umumnya angkutan pengumpan ini menaikkan dan menurunkan penumpang transjakarta di area-area yang keberadaannya masih agak jauh dari halte Transjakarta.

Meskipun demikian transjakarta masih memiliki beberapa kekurangan yang harus diperbaiki selama pengoperasiannya. Hal-hal yang dinilai harus ditingkatkan antara lain adalah headway Transjakarta, kondisi halte Transjakarta, lokasi halte transjakarta, kelayakan armada transjakarta, dan sterilisasi jalur Transjakarta. Namun yang tidak kalah penting dalam upaya mengembangkan dan memperbaiki sistem Transjakarta adalah kesadaran masyarakat Jakarta untuk beralih dan lebih mendukung moda transportasi ini.

Maka dari itu, penulis secara khusus akan membahas dan meneliti lebih dalam tentang jalan Gatot Subroto. Jalan Gatot Subroto dipilih karena merupakan salah satu jalan protokol termacet di kota Jakarta pada pagi dan sore hari (rush hour) serta banyak dilalui oleh berbagai bus Transjakarta dari berbagai koridor yang berbeda.

\section{Transjakarta}

Transjakarta merupakan sebuah sistem transportasi Bus Rapid Transit (BRT) pertama di Asia Tenggara dan Selatan dengan jalur lintasan terpanjang di dunia (208 km). Menurut Saksono, Darmaningtyas dan Waro (2012), sistem BRT ini didesain berdasarkan sistem TransMilenio di Bogota, Kolombia. Transjakarta resmi beroperasi sejak 1 Februari 2004. Transjakarta dipilih oleh Sutiyoso, Gubernur DKI Jakarta periode 1997-2007 karena biayanya jauh lebih murah jika dibandingkan dengan moda transportasi lainnya seperti monorel atau subway. Pemprov DKI Jakarta juga menyadari pentingnya membuat peraturan perundangan yang dapat menjadi dasar pengoperasian Transjakarta. Peraturan tersebut berupa Peraturan Daerah (Perda) Nomor 12 Tahun 2003 tentang Lalu Lintas dan Angkutan Jalan, Kereta Api, Sungai, Danau, dan Penyeberangan. Perda itu ditandatangani Gubernur Sutioyoso pada 31 Desember 2003.

Dalam menjalankan tugasnya menyelenggarakan jasa transportasi umum massal di Jakarta, Transjakarta mempunyai visi untuk menjadi angkutan umum yang mampu memberikan pelayanan publik yang cepat, aman, nyaman, manusiawi, efisien, berbudaya, dan bertaraf internasional. Sedangkan misi yang diemban, awalnya adalah:

a. Melaksanakan reformasi sistem angkutan umum dan budaya penggunaan angkutan.

b. Menyediakan pelayanan yang lebih dapat diandalkan, berkualitas tinggi, berkeadilan, dan berkesinambungan di wilayah DKI Jakarta.

c. Memberikan solusi jangka menengah dan jangka panjang terhadap permasalahan di sector angkutan umum.

d. Menerapkan mekanisme pendekatan dan sosialisasi terhadap stakeholder dan sistem transportasi terintegrasi.

e. Mempercepat implementasi sistem jaringan di Jakarta yang sesuai dengan aspek kepraktisan, kemampuan masyarakat untuk menerima sistem tersebut, dan kemudahan pelaksanaan.

f. Mengembangkan struktur institusi yang berkesinambungan.

g. Mengembangkan lembaga pelayanan masyarakat dengan pengelolaan keuangan yang berdasarkan good corporate governance, akuntabilitas, dan transparansi.

Seiring berjalannya waktu dan perubahan organisasi, visi dan misi Transjakarta berubah menjadi seperti berikut: Visi : Menghubungkan kehidupan Jakarta. Misi:Bersama-sama menyediakan layanan transportasi terintegrasi yang memudahkan dan membahagiakan kehidupan Jakarta.

Menurut Susilo dan Leontan (2007), Bus yang digunakan sebagai bus Transjakarta pada umumnya adalah Bus Mercedes-Benz dan Hino dengan warna bus adalah merah dan kuning sedangkan bahan bakar yang digunakan 
adalah biosolar. Dibandingkan dengan bus lain, bus Transjakarta mempunyai pintu yang terletak lebih tinggi sehingga hanya dapat ditumpangi dari halte khusus busway (shelter). Menerapkan sistem lipat otomatis pada bagian pintu yang dapat dikendalikan dari konsol yang ada di panel pengemudi, pintu tersebut terletak dibagian tengah kanan dan kiri dengan.

\section{Electronic Road Pricing (ERP)}

Electronic Road Pricing adalah sistem ruas jalan berbayar dimana kendaraan akan terkena biaya bila memasuki area yang dipasang alat ini. Berbeda dengan jalan tol, jalan dengan alat Electronic Road Pricing tidak harus menunggu palang otomatis, hanya dengan melewati sudah dapat terbayar dan melewati jalan. Electronic Road Pricing di Jakarta bekerja bila kendaraan memiliki OBU (On Board Unit) dan akan terkena biaya bila melewati kawasan ini.

Menurut Susanto (2008) Kebijakan Travel Demand Management dapat dibagi menjadi tiga group, yaitu: instrumeninstrumen regulasi (regulation instruments), persetujuan-persetujuan kerjasama (cooperative agreements), dan instrumen-instrumen ekonomi (economic instruments). Congestion pricing (pungutan biaya kemacetan) merupakan salah satu economic instrument yang bertujuan untuk mengurangi penggunaan kendaraan pribadi.

\section{Stated Preference}

Perumusan model dalam pendekatan pemecahan masalah penelitian ini digunakan pendekatan teori pemilihan diskrit, dengan teknik pengumpulan data yang dipilih yaitu menggunakan teknik stated preference pada level disagregat dengan asumsi bahwa yang membuat keputusan dalam memilih moda adalah individu pelaku perjalanan itu sendiri, yaitu pemilik atau pengirim barang (shippers) dan perusahaan jasa angkutan barang. Teknik stated preference dipilih karena secara umum dapat memberikan gambaran yang efektif dalam meramalkan perubahan permintaan dan perilaku perjalanan. Disamping itu juga dengan perencanaan desain eksperimen yang baik pada teknik stated preference ini akan dapat mengukur permintaan dan perilaku perjalanan dengan kualitas informasi yang baik pula, sesuatu yang tidak bisa dilakukan dengan teknik konvensional. Bahkan menurut Putra (2015), dengan teknik stated preference peneliti dapat melakukan kontrol eksperimen kehidupan nyata dalam sistem transportasi.

Teknik stated preference ini memiliki beberapa keuntungan, yaitu:

a. Peneliti dapat mengontrol pilihan yang ditawarkan kepada responden dengan tepat. Teknik stated preference dapat memastikan bahwa data yang dihasilkan baik untuk membangun model statistik.

b. Pengaruh variabel dalam pilihan terisolasi dari pengaruh variabelvariabel lain;

c. Teknik stated preference dapat digunakan untuk evaluasi dan peramalan sebuah kebijakan.

d. Model statistik dapat dihasilkan dari ukuran sampel yang kecil.

\section{METODE PENELITIAN}

Tahapan penelitian menggambarkan proses keseluruhan dari penelitian ini yang berfokus pada Jalan Gatot Subroto, yaitu khususnya pada halte busway Gatot Subroto Jamsostek. Pada awalnya, penelitian ini akan mengumpulkan data dengan metode pengamatan/observasi langsung kemudian wawancara/angket kuesioner individual dengan metode stated preference. Kemudian mengidentifikasikan data yang ada, lalu menyusun formulir survei yang akan diuji coba sebelum formulir survei disebarkan sebagai kuesioner akhir. Dilakukan pengambilan data primer dari hasil observasi dan pembagian kuesioner.

Data yang diperoleh dari kuesioner berupa data penduduk yang akan pindah dari transportasi pribadi / transportasi online ke Transjakarta. Data tersebut kemudian akan dianalisa lebih lanjut. Dari data observasi dan kuesioner akan ditentukan tarif ERP yang efisien. Setelah menyelesaikan semua penelitian hingga hasil akhir, dapat ditentukan seberapa banyak penduduk yang akan pindah dari transportasi pribadi / transportasi online ke Transjakarta.

\section{Metode pengumpulan data}

Survei yang akan dilakukan dengan cara pengamatan langsung ditempat adalah salah satu metode primer dalam penelitian ini yang mencangkup banyak hal seperti kapasitas jalan, kecepatan rata - rata, volume lalu lintas, dan tingkat kepuasan pelayanan lalu lintas di ruas jalan Gatot Subroto. Data - data yamg digunakan dalam penulisan ini diambil dari penulisan sebelumnya. Selain pengamatan secara langsung, survei ini didukung juga dengan survei wawancara atau kuesioner yang dimana hasil dari kuesioner ini akan digunakan untuk memodifikasi hasil survei pengamatan. Kuesioner ini berisi tentang tingkat keinginan penggunaan jalan bila diberikan sistem jalan berbayar atau Electronic Road Pricing. Skala keinginan diukur dalam tingkat kepuasan dari keinginan meneruskan menggunakan kendaraan pribadi atau berganti moda perjalanan dengan menggunakan kerndaraan umum. Besarnya keinginan pengguna jalan untuk berpindah moda perjalanan akan menurunkan angka kapasitas dari hasil observasi. 
Subroto

Pengumpulan data dengan kuesioner akan diolah dengan menganalisa sudut pandang pada pengguna jalan yang menggunakan jalan Gatot Subroto. Kemudian data tersebut akan dianalisa untuk mendapatkan modelnya.

\section{HASIL DAN PEMBAHASAN}

Data diambil dengan menggunakan kuesioner secara langsung sebanyak 62 responden. Analisis ini akan memberikan gambaran seberapa besar perubahan lalu lintas bila ERP telah dijalankan. Data yang diperoleh dari hasil kuesioner kemudian akan dikombinasikan dengan hasil pengamatan langsung. Hasil dari pengamatan langsung dikompilasi untuk membuat regresi linear hubungan kepadatan lalu lintas dan kecepatan lalu lintas disetiap ruas jalan dengan bantuan program microsoft excel. Data responden yang akan disajikan terdiri dari alternatif kendaraan selain mobil pribadi, alas an menggunakan moda transportasi lain, umur, jenis kelamin, tempat tinggal, tingkat pendidikan, golongan pekerjaan, rata-rata pendapatan, maksud perjalanan, dan biaya perbulan untuk perjalanan rutin. Hasil kuesioner pemilihan tarif ERP oleh responden dapat dilihat pada Tabel 1, sedangkan analisis kapasitas Jalan Gatot Subroto seberang JCC dapat dilihat pada Tabel 2 dan analisis kapasitas Jalan Gatot Subroto depan JCC dapat dilihat pada Tabel 3. Grafik hubungan kecepatan dan kepadatan arah seberang JCC Senayan dapat dilihat pada gambar 1, sedangkan grafik hubungan kecepatan dan kepadatan arah depan JCC Senayan dapat dilihat pada gambar 2 .

Tabel 1. Hasil kuesioner pemilihan tarif ERP

\begin{tabular}{|c|c|c|c|c|c|c|}
\hline \multirow[b]{2}{*}{ No. } & \multicolumn{2}{|c|}{$\begin{array}{c}\text { Kondisi Perjalanan Setelah } \\
\text { Penerapan ERP }\end{array}$} & \multicolumn{4}{|c|}{ Pilihan (beri tanda X) } \\
\hline & $\begin{array}{l}\text { Tarif } \\
\text { ERP } \\
(\mathrm{Rp})\end{array}$ & Waktu Perjalanan *) & $\begin{array}{c}\text { Pasti } \\
\text { memilih } \\
\text { jalan }+ \\
\text { ERP }\end{array}$ & $\begin{array}{c}\text { Mungkin } \\
\text { memilih } \\
\text { jalan + } \\
\text { ERP }\end{array}$ & $\begin{array}{c}\text { Mungkin } \\
\text { tidak } \\
\text { memilih } \\
\text { jalan + } \\
\text { ERP }\end{array}$ & $\begin{array}{l}\text { Pasti } \\
\text { tidak } \\
\text { memilih } \\
\text { jalan + } \\
\text { ERP }\end{array}$ \\
\hline 1 & 15 & Lebih cepat 10 menit & 18 & 15 & 11 & 6 \\
\hline 2 & 30 & Lebih cepat 20 menit & 19 & 21 & 10 & 0 \\
\hline 3 & 40 & Lebih cepat 30 menit & 13 & 11 & 21 & 5 \\
\hline 4 & 50 & Lebih cepat 40 menit & 0 & 2 & 25 & 23 \\
\hline 5 & 60 & Lebih cepat 45 menit & 0 & 0 & 2 & 48 \\
\hline 6 & 65 & Lebih cepat 50 menit & 0 & 0 & 1 & 49 \\
\hline
\end{tabular}

Tabel 2. Analisis kapasitas Jalan Gatot Subroto seberang JCC

\begin{tabular}{ccccccccc}
\hline Waktu & $\begin{array}{c}\text { Jarak } \\
(\mathrm{m})\end{array}$ & $\begin{array}{c}\text { Tidak } \\
\text { Bermotor }\end{array}$ & Parkir & Keluar/Masuk & $\begin{array}{c}\text { Pejalan } \\
\text { Kaki }\end{array}$ & Hambatan & $\begin{array}{c}\text { Kode } \\
\text { Hambatan }\end{array}$ & C \\
\hline $\begin{array}{c}07.00- \\
09.00\end{array}$ & 200 & 12 & 43 & 0 & 0 & 47,8 & VL & $4,939,506$ \\
\hline $\begin{array}{c}13.00- \\
15.00\end{array}$ & 200 & 6 & 34 & 0 & 0 & 36,4 & VL & $4,939,506$ \\
\hline $\begin{array}{c}16.00- \\
18.00\end{array}$ & 200 & 4 & 36 & 0 & 0 & 37,6 & VL & $4,939,506$ \\
\hline
\end{tabular}


Tabel 3. Analisis kapasitas Jalan Gatot Subroto depan JCC

\begin{tabular}{ccccccccc}
\hline Waktu & $\begin{array}{c}\text { Jarak } \\
(\mathrm{m})\end{array}$ & $\begin{array}{c}\text { Tidak } \\
\text { Bermotor }\end{array}$ & Parkir & Keluar/Masuk & $\begin{array}{c}\text { Pejalan } \\
\text { Kaki }\end{array}$ & Hambatan & $\begin{array}{c}\text { Kode } \\
\text { Hambatan }\end{array}$ & $\mathrm{C}$ \\
\hline $\begin{array}{c}07.00- \\
09.00\end{array}$ & 200 & 14 & 36 & 33 & 0 & 64,7 & VL & $4,939,506$ \\
\hline $\begin{array}{c}13.00- \\
15.00\end{array}$ & 200 & 6 & 22 & 35 & 0 & 48,9 & VL & $4,939,506$ \\
\hline $\begin{array}{c}16.00- \\
18.00\end{array}$ & 200 & 15 & 28 & 48 & 0 & 67,6 & VL & $4,939,506$ \\
\hline
\end{tabular}

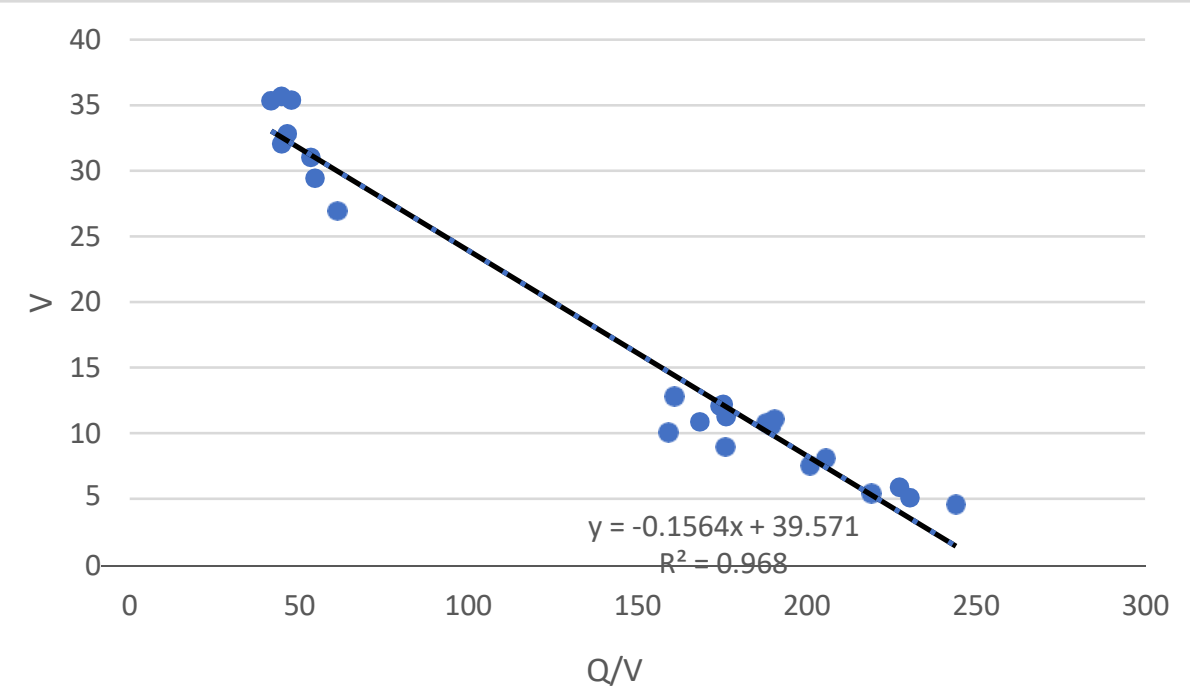

Gambar 1. Grafik hubungan kecepatan dan kepadatan arah seberang JCC Senayan

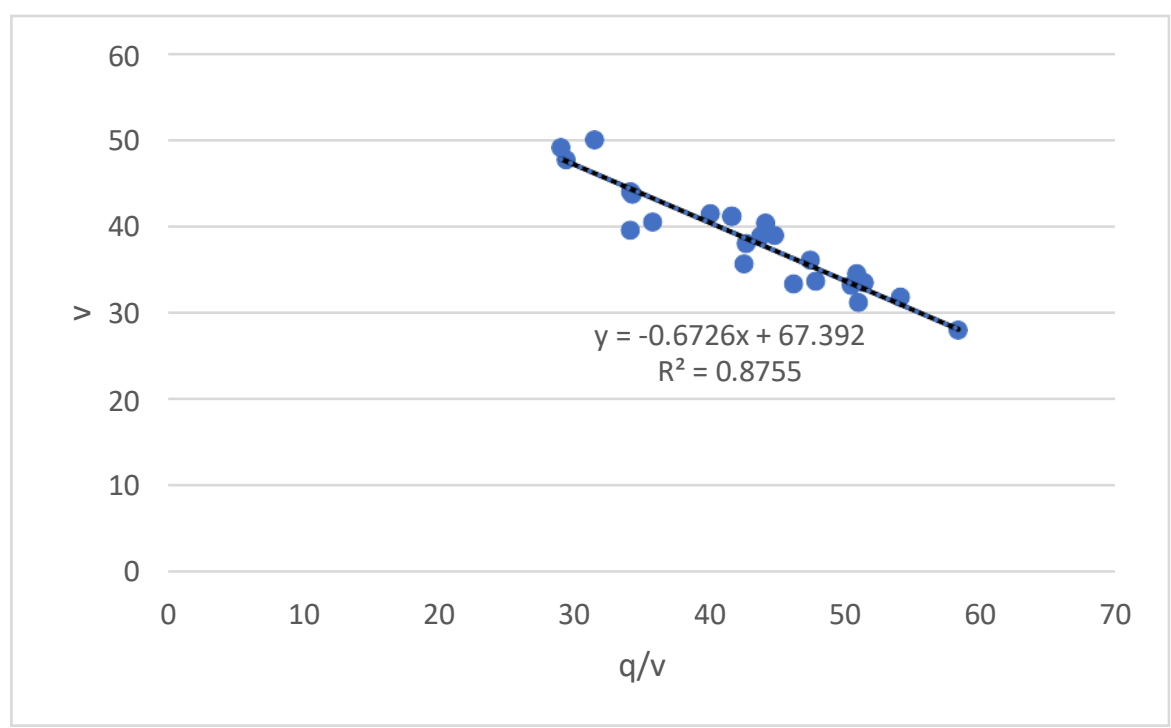

Gambar 2. Grafik hubungan kecepatan dan kepadatan arah depan JCC Senayan 


\section{Analisis kuisioner presepsi responden terhadap pilihan bus transjakarta sebagai alternatif pengganti kendaraan pribadi}

Dari kuesioner yang telah dihitung menggunakan analisis statistik metode regresi didapatkan persamaan sebagai berikut:

$$
\mathrm{Y}=0,00001-0,1543 * \mathrm{X} 1-0,0443 * \mathrm{X} 2
$$

Variabel X1 menunjukkan waktu tempuh feeder sedangkan variabel X2 menunjukkan waktu tempuh perjalanan secara keseluruhan. Pemodelan yang telah didapat bisa dilihat pada Tabel 4.

Tabel 4. Tabel pemodelan

\begin{tabular}{|c|c|c|}
\hline \multicolumn{3}{|c|}{$\begin{array}{c}\mathrm{Y}=0,00001-(0,1543 * \mathrm{X} 1)- \\
(0,0443 * \mathrm{X} 2)\end{array}$} \\
\hline $\mathrm{X} 1$ & $\mathrm{X} 2$ & Y \\
\hline-5 & -30 & 2,10051 \\
\hline-10 & -25 & 2,65051 \\
\hline-15 & -20 & 3,20051 \\
\hline-20 & -15 & 3,75051 \\
\hline-25 & -10 & 4,30051 \\
\hline
\end{tabular}

Dari hasil yang diperhitungkan dan analisis yang telah dilakukan, maka diperoleh sebagai berikut:

1. Dari hasil data jawaban responden dapat disimpulkan bahwa waktu tempuh feeder lebih cepat 20 menit dan waktu tempuh perjalanan lebih cepat 25 menit merupakan waktu yang paling diminati oleh reponden karena sebanyak 39 responden memilih skema waktu tersebut.

2. Dari hasil analisis data dapat dilihat pada masing - masing ruas jalan mengalami kenaikan kecepatan dan volume mengalami pengurangan.

3. Dari hasil pengujian model menggunakan metode regresi linier dapat dilihat bahwa X1 dan X2 mempengaruhi hasil Y, hal ini menunjukan bahwa waktu tempuh feeder lebih cepat 20 menit dan waktu tempuh perjalanan lebih cepat 15 menit merupakan waktu yang ideal.

\section{KESIMPULAN DAN SARAN}

\section{Kesimpulan}

Berdasarkan penelitian yang telah dilakukan, maka dapat diperoleh kesimpulan sebagai berikut:

1. Dari hasil pengamatan langsung dapat disimpulkan bahwa peningkatan kendaraan terjadi pada pukul $07.00-$ 09.00 dan pada pukul 16.00 - 18.00. Hal ini disebabkan karena jumlah pengguna jalan yang meningkat drastis pada saat jam masuk kerja dan pulang kerja.

2. Dari hasil kuesioner yang disebar dapat diketahui bahwa responden cenderung lebih memilih waktu tempuh feeder Transjakarta dipercepat 20 menit dan waktu tempuh perjalanan secara keseluruhan dipercepat selama 25 menit pada saat ERP telah diterapkan.

3. Dari hasil analisis statistik dengan metode regresi dapat disimpulkan bahwa mepercepat waktu tempuh feeder hingga 20 menit dan waktu tempuh perjalanan hingga 15 menit merupakan hal yang efektif karena pengguna kendaraan pribadi akan cenderung memilih menggunakan bus Transjakarta dengan kondisi ERP telah diterapkan.

\section{Saran}

Berdasarkan penelitian yang telah dilakukan, maka terdapat beberapa saran sebagai berikut:

1. Penelitian yang sama perlu dilakukan secara lebih mendalam pada ruas - ruas jalan yang saat ini diberlakukan ganjil genap dan merupakan jalan protokol.

2. Perlu melakukan survei lalu lintas selama setidaknya satu hari penuh untuk mendapatkan lebih banyak variasi kondisi lalu lintas saat kondisi memang sudah memungkinkan (setelah masa pandemi berlalu). 


\section{DAFTAR PUSTAKA}

Abubakar, Iskandar. "Manajemen Lalu Lintas". Jakarta: TRANSINDO Gastama Media, 2012.

Putra, Agung Nugroho. “Stated Preference Kebutuhan Angkutan”. (2015). Web. 3 Juni. 2020.

Saksono, Bani, Darmaningtyas dan Achmad Izzul Waro. Manajemen Transjakarta Busway. Jakarta: Transindo Gastama Media, 2012.

Susantono, Bambang. "Electronic Road Pricing (ERP) Salah Satu Solusi Masalah Kemacetan di Kota Jakarta". Jakarta: Buletin Tata Ruang, 2008. Web. 18 Februari. 2020.

Susilo, Budi Hartanto dan Apriyanto Leontan. "Kajian Operasi Bus Rapid Transit Transjakarta dan Transmilenio Bogota”. (2007). Web 20 Juni. 2020. 
Pengaruh Penerapan ERP terhadap Waktu Tempuh Feeder

Sherly Octaviani, et al. dan Waktu Tempuh Perjalanan pada Ruas Jalan Gatot

Subroto 